\title{
Convalescent plasma transfusion therapy in severe COVID-19 patients- a safety, efficacy and dose response study: A structured summary of a study protocol of a phase II randomized controlled trial
}

Fazle Rabbi Chowdhury ${ }^{1 *+}$ (D), Ashraful Hoque ${ }^{2+}$, Forhad Uddin Hasan Chowdhury ${ }^{3}$, Md. Ruhul Amin ${ }^{4}$, Abdur Rahim ${ }^{5}$, M. Mujibur Rahman³, Rubina Yasmin ${ }^{6}$, Md. Robed Amin ${ }^{3}$, Md. Titu Miahn', Md. Abul Kalam² and Md. Sayedur Rahman ${ }^{1,7}$

\begin{abstract}
Objectives: General: To assess the safety, efficacy and dose response of convalescent plasma (CP) transfusion in severe COVID-19 patients

Specific:

a. To identify the appropriate effective dose of CP therapy in severe patients

b. To identify the efficacy of the therapy with their end point based on clinical improvement within seven days of treatment or until discharge whichever is later and in-hospital mortality

c. To assess the clinical improvement after CP transfusion in severe COVID-19 patients

d. To assess the laboratory improvement after CP transfusion in severe COVID-19 patients
\end{abstract}

Trial Design: This is a multicentre, multi-arm phase II Randomised Controlled Trial.

Participants: Age and sex matched COVID-19 positive (by RT-PCR) severe cases will be enrolled in this trial. Severe case is defined by the World Health Organization (W.H.O) clinical case definition. The inclusion criteria are

1. Respiratory rate $>30$ breaths/min; PLUS

2. Severe respiratory distress; or $\mathrm{SpO} 2 \leq 88 \%$ on room air or $\mathrm{PaO} 2 / \mathrm{FiO} 2 \leq 300 \mathrm{~mm}$ of $\mathrm{Hg}$, PLUS

3. Radiological (X-ray or CT scan) evidence of bilateral lung infiltrate, AND OR

4. Systolic BP $<90 \mathrm{~mm}$ of $\mathrm{Hg}$ or diastolic $\mathrm{BP}<60 \mathrm{~mm}$ of $\mathrm{Hg}$.

AND/OR

5. Criteria 1 to 4 AND or patient in ventilator support

Patients' below18 years, pregnant and lactating women, previous history of allergic reaction to plasma, patients

(Continued on next page)

\footnotetext{
* Correspondence: rabbimedicine@bsmmu.edu.bd

Fazle Rabbi Chowdhury and Ashraful Hoque are joint first.

'Department of Internal Medicine, Bangabandhu Sheikh Mujib Medical University (BSMMU), Dhaka, Bangladesh

Full list of author information is available at the end of the article
}

C The Author(s). 2020 Open Access This article is licensed under a Creative Commons Attribution 4.0 International License, which permits use, sharing, adaptation, distribution and reproduction in any medium or format, as long as you give appropriate credit to the original author(s) and the source, provide a link to the Creative Commons licence, and indicate if changes were made. The images or other third party material in this article are included in the article's Creative Commons licence, unless indicated otherwise in a credit line to the material. If material is not included in the article's Creative Commons licence and your intended use is not permitted by statutory regulation or exceeds the permitted use, you will need to obtain permission directly from the copyright holder. To view a copy of this licence, visit http://creativecommons.org/licenses/by/4.0/. The Creative Commons Public Domain Dedication waiver (http://creativecommons.org/publicdomain/zero/1.0/) applies to the data made available in this article, unless otherwise stated in a credit line to the data. 
(Continued from previous page)

who have already received plasma from a different source will be excluded. Patients will be enrolled at Bangabandhu Sheikh Mujib Medical University (BSMMU) hospital, Dhaka medical college hospital (DMCH) and Mugda medical college hospital (MuMCH). Apheretic plasma will be collected at the transfusion medicine department of SHNIBPS hospital, ELISA antibody titre will be done at BSMMU and CMBT and neutralizing antibody titre will be checked in collaboration with the University of Oxford.

Patients who have recovered from COVID-19 will be recruited as donors of CP. The recovery criteria are normality of body temperature for more than 3 days, resolution of respiratory symptoms, two consecutively negative results of sputum SARS-CoV-2 by RT-PCR assay (at least 24 hours apart) 22 to 35 days of post onset period, and neutralizing antibody titre $\geq 1: 160$.

Intervention and comparator: This RCT consists of three arms, a. standard care, b. standard care and $200 \mathrm{ml}$ CP and c. standard care and $400 \mathrm{ml} \mathrm{CP}$. Patients will receive plasma as a single transfusion. Intervention arms will be compared to the standard care arm.

Main outcomes: The primary outcome will be time to clinical improvement within seven days of treatment or until discharge whichever is later and in-hospital mortality. The secondary outcome would be improvement of laboratory parameters after therapy (neutrophil, lymphocyte ratio, CRP, serum ferritin, SGPT, SGOT, serum creatinine and radiology), length of hospital stay, length of ICU stay, reduction in proportion of deaths, requirement of ventilator and duration of oxygen and ventilator support.

Randomisation: Randomization will be done by someone not associated with the care or assessment of the patients by means of a computer generated random number table using an allocation ratio of 1:1:1.

Blinding (masking): This is an open level study; neither the physician nor the patients will be blinded. However, the primary and secondary outcome (oxygen saturations, PaO2/FiO2, BP, day specific laboratory tests) will be recorded using an objective automated method; the study staff will not be able to influence the recording of these data.

Number to be randomised (sample size): No similar study has been performed previously. Therefore no data are available that could be used to generate a sample size calculation. This phase II study is required to provide some initial data on efficacy and safety that will allow design of a larger study. The trial will recruit 60 participants (20 in each arm).

Trial Status: Protocol version 1.4 dated May 5, 2020 and amended version 1.5, dated June 16, 2020. First case was recruited on May 27, 2020. By August 10, 2020, the trial had recruited one-third (21 out of 60) of the participants. The recruitment is expected to finish by October 31, 2020.

Trial registration: Clinicaltrials.gov ID: NCT04403477. Registered 26 May, 2020

Full Protocol: The full protocol is attached as an additional file, accessible from the Trial's website (Additional file 1). In the interest in expediting dissemination of this material, the familiar formatting has been eliminated; this letter serves as a summary of the key elements of the full protocol.

Keywords: Convalescent plasma, severe COVID-19, Randomised controlled trial, SARS-CoV-2, BSMMU

\section{Supplementary information}

Supplementary information accompanies this paper at https://doi.org/10. 1186/s13063-020-04734-z.

\section{Additional file 1.}

\section{Acknowledgements}

We are grateful to Prof. Susanna Dunachie and Prof. Paul Klenerman of the University of Oxford for their technical and logistic support. We acknowledge the laboratory support of the Department of Biochemistry, BSMMU. We also acknowledge the contributions of all the health care workers and hospital administration of the study sites.

\section{Authors' Contributions}

MSR, FRC and AH conceptualized the whole trial. FUHC, MMR and MRA are recruiting patients at DMCH. RY and MTM are recruiting patients at MuMCH.
FRC and MSR are recruiting patients at BSMMU. AH will screen, collect and process apheretic CP. RA will do the antibody titre. AR and MAK are involved with the selection of potential donor, monitoring, and proposal write up. All authors have read and approved the final manuscript.

\section{Funding}

The trial will be funded by BSMMU grant number, 2020/7231(01). The funding body has no influence in the design of the study and data collection, analysis and interpretation of data and in writing the manuscript.

\section{Availability of data and materials}

The principal investigator (PI) and an independent two member's data monitoring committee (DMC) has full access to the data. Data would be made available upon request to the PI during the process of publication if required. 


\section{Ethics approval and consent to participate}

The trial received ethical clearance from BSMMU institutional review board (IRB) on May 20, 2020, registration number: BSMMU/2020/6104. We certify that this trial has received ethical approval from the appropriate ethical committee as described above. Informed written consent is taken from the patient or their attendant (first-degree relatives such as adult siblings or parents or brothers/sisters or spouse).

\section{Consent for publication}

Not applicable

\section{Competing interests}

The authors declare that they have no competing interest.

\section{Author details}

'Department of Internal Medicine, Bangabandhu Sheikh Mujib Medical University (BSMMU), Dhaka, Bangladesh. ${ }^{2}$ Department of Blood Transfusion, Sheikh Hasina National Institute of Burn and Plastic Surgery (SHNIBPS), Dhaka, Bangladesh. ${ }^{3}$ Department of Medicine, Dhaka Medical College, Dhaka, Bangladesh. ${ }^{4}$ Centre for Medical Biotechnology, Mohakhali, Dhaka, Bangladesh. ${ }^{5}$ Kuwait Bangladesh Friendship Government Hospital, Dhaka, Bangladesh. 'Department of Medicine, Mugda Medical College, Dhaka, Bangladesh. ${ }^{7}$ Department of Pharmacology, Bangabandhu Sheikh Mujib Medical University, Dhaka, Bangladesh.

Received: 4 September 2020 Accepted: 8 September 2020

Published online: 26 October 2020

\section{Publisher's Note}

Springer Nature remains neutral with regard to jurisdictional claims in published maps and institutional affiliations.

- fast, convenient online submission

- thorough peer review by experienced researchers in your field

- rapid publication on acceptance

- support for research data, including large and complex data types

- gold Open Access which fosters wider collaboration and increased citations

- maximum visibility for your research: over $100 \mathrm{M}$ website views per year

At $\mathrm{BMC}$, research is always in progress. 